\title{
Carboxymethyl Cellulose Film Optimized with Persian Gum, Titanium Dioxide Nanoparticles, and Fennel Essential Oil: Investigation of Chemical, Antimicrobial, and Sensory Properties on Rainbow Trout Fillet
}

mohammad maleki

Ferdowsi University of Mashhad

Mohammad Mohsenzadeh ( $\nabla$ mohsenzadeh@um.ac.ir)

Ferdowsi University of Mashhad https://orcid.org/0000-0002-7829-039X

Research Article

Keywords: Antibacterial, MIC, MBC, Fennel Essential Oil

Posted Date: November 3rd, 2021

DOI: https://doi.org/10.21203/rs.3.rs-1043290/v1

License: (c) (i) This work is licensed under a Creative Commons Attribution 4.0 International License.

Read Full License 


\section{Abstract}

Today, the use of biodegradable packaging containing antimicrobial agents has been approved by the people and industry. In this study, the effect of carboxymethyl cellulose (CMC) film optimized with Persian gum (PG) containing titanium dioxide nanoparticles $\left(\mathrm{TiO}_{2}\right)$ and fennel essential oil (FEO) was inspected and the sensory, chemical, and microbial properties were evaluated on refrigerated rainbow trout fillets during the storage period $(0,3,6,9$, and 12 days). The lowest values for the minimum inhibitory concentration (MIC) $(8 \mathrm{mg} / \mathrm{mL})$ and the minimum bactericidal concentration (MBC) $(10$ $\mathrm{mg} / \mathrm{mL}$ ), and the highest diameter of the inhibitory zone in the disk diffusion $(19 \mathrm{~mm})$ for FEO were observed against Listeria monocytogenes, Escherichia coli.0157:H7, Pseudomonas fluorescens, and Shewanella putrefaciens, respectively. Moreover, as a microbiological analysis, total viable count (TVC), Pseudomonas spp, lactic acid bacteria (LAB), Enterobacteriaceae, and psychrotrophic bacteria were determined on rainbow trout fillets covered with different treatments (CMC/PG, CMC/PG/FEO, $\mathrm{CMC} / \mathrm{PG} / \mathrm{TiO}_{2}$, and $\mathrm{CMC} / \mathrm{PG} / \mathrm{FEO} / \mathrm{TiO}_{2}$ ) during the storage at $4^{\circ} \mathrm{C}$. The results showed that three treatments of $\mathrm{CMC} / \mathrm{PG} / \mathrm{FEO}, \mathrm{CMC} / \mathrm{PG} / \mathrm{TiO}_{2}$, and $\mathrm{CMC} / \mathrm{PG} / \mathrm{FEO} / \mathrm{TiO}_{2}$ had a significant effect on growth control in the studied bacteria $(P<0.05)$. In all treatments, the amount of thiobarbituric acid increased over time, but in the treatment containing FEO, this amount was lower. Sensory scores of the samples were very high until day 6 . In general, the results of this study showed that the use of FEO and $\mathrm{TiO}_{2}$ in biodegradable films improves the antimicrobial, chemical, and sensory properties of rainbow trout fillets.

\section{Introduction}

Foods are always exposed to chemical, microbial, and physical spoilage and food preservation plays an essential role in controlling changes during the storage of different products such as fresh vegetables, fruits, and meats [1]. This would lead to the increased shelf life through inhibiting the oxidative changes and growth of microorganisms [2][3].

Films are thin layers around food that prevent the transfer of moisture and oxygen, as well as solutes to the food. In this regard, active packaging is designed to preserve the packaged material in the best possible manner according to the storage conditions of the package so that the food reaches the consumer in appropriate conditions.

In general, biodegradable films are made from three main components: protein, lipid, or polysaccharide; these materials can be used alone or in combination with each other. The physical and chemical properties of these materials remarkably influence the properties of the films [4].

Carboxymethyl cellulose (CMC) is known as a water-soluble cellulose derivative owing good film-forming properties [5]. It is capable of forming colorless, water soluble, non-toxic, stable, and uniform film-forming solution albeit with poor mechanical properties [6]. Persian gum (PG) is obtained from the wild almond tree (Amygdalu scoparia Spach) and is available in white to dark colors, in different shapes and sizes. This gum dissolves easily in hot water [7][8]. 
Films used in the food industry may contain a variety of substances, including antioxidants, antimicrobials, and flavorings. This type of packaging prevents the activity of pathogenic and spoilage microorganisms during the storage and increases the shelf life [9].

Biodegradable films are supplemented with essential oils to improve the antimicrobial-antioxidant effects, the aroma of the film, and the permeability properties of hydrophilic films [10]. Fennel (Foeniculum vulgare Mill) is a biennial or perennial herbaceous plant of the Umbelliferae family, and fennel essential oil (FEO) has antiseptic, antifungal, anti-flatulence, and appetizing properties [11].

Silver, zinc oxide, copper, and titanium dioxide nanoparticles $\left(\mathrm{TiO}_{2}\right)$ are the most important nanoparticles used in the production of nanocomposites, with many applications, and antimicrobial and optical properties [12]. $\mathrm{TiO}_{2}$, used in the structure of nanocomposites, prevents the growth of pathogenic microorganisms in addition to improving their properties [13]. It is widely used in the film in the range of 0.5 to $1 \mathrm{w} / \mathrm{w}$, based on dry matter weight [14].

$\mathrm{CMC}$ film with $\mathrm{PG}, \mathrm{TiO}_{2}$, and $\mathrm{FEO}$ has desirable physical and mechanical properties [15]. Packaging the refrigerated rainbow trout fillet with the biodegradable film of CMC/PG, containing $\mathrm{TiO}_{2}$ and FEO, and subsequently, the study of microbial, chemical, and sensory properties of the film on rainbow trout fillet at refrigeration temperatures were the objectives of this study.

\section{Materials And Methods}

CMC (viscosity of $1 \%$ solution in water at $20^{\circ} \mathrm{C}$ is $1500-3500$ centipoise, with a pKa of 3.5), PG (Parsian Gam Reyhan, Isfahan, Iran), FEO (Johare Taem Shargh, Mashhad, Iran), glycerol, $\mathrm{TiO}_{2}$ (anatase, purity $>99 \%$ ), and other consumables were purchased from Merck, Germany.

\subsection{Preparation of biodegradable film}

To prepare the treatments (CMC/PG, CMC/PG/FEO, CMC/PG/TiO ${ }_{2}$, and CMC/PG/FEO/TiO ${ }_{2}$ ), $1.25 \mathrm{~g}$ of CMC was added to $100 \mathrm{~mL}$ of water at $60^{\circ} \mathrm{C}$ and mixed with a mixer for $15 \mathrm{~min}$. Then PG solution $(0.65 \%$ $\mathrm{w} / \mathrm{w})$, glycerol $(40 \% \mathrm{w} / \mathrm{w})$, FEO $(2 \% \mathrm{w} / \mathrm{v})$, and $\mathrm{TiO}_{2}(0.5 \% \mathrm{w} / \mathrm{w})$ were added to the film solution and mixed with a stirrer for $15 \mathrm{~min}$. To remove the air bubbles, an ultrasound bath (Schaper Unique USC $25 \mathrm{KHz}$ ) with a frequency of $25 \mathrm{KHz}$ and a field strength of $100 \mathrm{~W}$ was used for $15 \mathrm{~min}$. Then it was dried at $37^{\circ} \mathrm{C}$ for $24 \mathrm{~h}$ in a hot air dryer [15].

\subsection{Determination of MIC and MBC of FEO}

Minimum inhibitory concentration (MIC) and minimum bactericidal concentration (MBC) were measured in vitro on pathogenic bacteria including Listeria monocytogenes ATCC 7644 and Escherichia coli 0157:H7 NCTC 12900, and the causative agents including Shewanella putrefaciens NCTC 10762 and Pseudomonas fluorescens NCTC 10038. Bacterial strains were cultured for $24 \mathrm{~h}$ at $37^{\circ} \mathrm{C}$ and $22^{\circ} \mathrm{C}$ in Müller-Hinton broth, respectively. Specific concentrations of FEO (in DMSO) were prepared and $20 \mu \mathrm{L}$ of it 
was added to 96 -well microplates containing $20 \mu \mathrm{L}$ bacterial suspension ( $0.5 \mathrm{McFarland})$ and $160 \mu \mathrm{L}$ sterile broth. Similar tests were performed for both positive control (culture medium containing bacteria without antimicrobial agent) and negative control (culture medium without bacteria). The microplates were kept in an incubator at $37^{\circ} \mathrm{C}$ and $22^{\circ} \mathrm{C}$ (Pseudomonas spp.) for $24 \mathrm{~h}$. The lowest concentration of FEO in which no turbidity was observed was reported as the MIC. Ten microliters were taken from all wells and cultured on a plate containing brain heart infusion $(\mathrm{BHI})$ agar. The plates were stored in the incubator at $37^{\circ} \mathrm{C}$ for $24 \mathrm{~h}$. The lowest concentration of FEO, which was associated with the absence of bacterial colony, was considered as MBC. All these tests were performed in triplicate [16].

\subsection{Antimicrobial activity of films by disc diffusion method}

Antimicrobial activity of the film was analyzed on S. putrefaciens, P. fluorescens, E. coli 0157: H7, and L. monocytogenes. To this end, the films were cut into discs (1 $\mathrm{cm}$ in diameter) and placed on Müller Hinton agar plates. First, $0.1 \mathrm{~mL}$ of the 24 -hour bacterial suspension containing the desired bacteria $\left(10^{6}-10^{5}\right.$ $\mathrm{CFU} / \mathrm{mL}$ ) was cultured freshly. The plates were inoculated at $37^{\circ} \mathrm{C}$ for $24 \mathrm{~h}$. The diameter of the growth inhibition halo was measured by an accurate caliper and its area was reported in terms of square millimeters [17].

\subsection{Preparation of rainbow trout samples and treatments}

Rainbow trout were obtained from reputable shopping centers in Mashhad and transferred to the laboratory in cold conditions. Cutting, abdominal emptying, and washing operations were performed. The fish meat was divided into the pieces of about $50 \mathrm{~g}$ with an average thickness of $2 \mathrm{~cm}$. The fish pieces were covered with films. The coated samples and controls were placed in sterile plastics and stored at refrigeration temperature $\left(4\right.$ to $5^{\circ} \mathrm{C}$ ). All samples were evaluated at intervals of $0,3,6,9,12$, and 15 days.

\subsection{Microbial analysis}

Ten grams of fish samples were transferred to $90 \mathrm{~mL}$ of peptone water $0.1 \%$ and mixed with a mixer (Lab Blender 400, Stomacher, USA) for $1 \mathrm{~min}$ at room temperature. Peptone water $0.1 \%$ was used to prepare serial dilutions and count the desired bacteria by placing them in a specific culture medium and the specific temperature of each bacterium [16].

For total viable count (TVC), nutrient agar medium was used by surface culture at $37^{\circ} \mathrm{C}$ for $48 \mathrm{~h}$. Pseudomonas spp. was determined on cetrimide fusidin cephaloridine agar (supplemented with selective supplements) at $22^{\circ} \mathrm{C}$ for $48 \mathrm{~h}$. Lactic acid bacteria (LAB) were cultured in deMan Rogosa Sharpe (MRS) anaerobic medium at $25^{\circ} \mathrm{C}$ for 5 days under anaerobic conditions. For Enterobacteriaceae count, $0.1 \mathrm{mg}$ of sample was inoculated in $10 \mathrm{~mL}$ of Violet Red Bile Glucose agar (VRBGA) culture medium. Then $10 \mathrm{~mL}$ of molten culture medium was poured on them and VRBGA medium was kept in a $30^{\circ} \mathrm{C}$ oven for $24 \mathrm{~h}$. To determine and count the psychrotrophic bacteria, $0.1 \mathrm{~mL}$ of the desired dilution was cultured completely and superficially on Tryptic Soy Agar (TSA). Samples were kept at $7^{\circ} \mathrm{C}$ for 10 days and then the colonies were counted [14][18]

\section{6. $\mathrm{pH}$}


Ten grams of each sample were homogenized in $100 \mathrm{~mL}$ of distilled water and then filtered. A digital pH meter was employed to measure the pH of the solution (Hanna pH meter, HI 221, Romania).

\subsection{Determination of TBA}

Thiobarbituric acid (TBA) was calculated according to Kirk and Sawyer (1991) using a spectrophotometer and expressed as mgMDA/kg tissue. The minced fish sample (200 mg) was dissolved in 1-butanol to reach a volume of $25 \mathrm{~mL}$. Then, $5 \mathrm{~mL}$ of the solution was mixed with $5 \mathrm{~mL}$ of TBA reagent and kept at $95^{\circ} \mathrm{C}$ for $2 \mathrm{~h}$ and then the adsorption value was read at $532 \mathrm{~nm}$ [19].

\subsection{Sensory evaluation}

Sensory evaluation of fish fillet samples with different treatments was done by 5 semi-skilled panelists. Each sample with 3 replicates were placed in separate plates without specifying the type of treatment. Panelists assessed color, odor, texture, and overall characteristics of acceptability using a 9-point rating scale. The scoring values were as follows: bad or unacceptable: 1-3; good: 4-6; very good: 7-8; and excellent: 9 [18].

\subsection{Statistical analysis}

In this study, SPSS software version 16.0 (IBM; Armonk, N. Y, USA) was applied and a thoroughly randomized factorial design was used to compare the results. All experiments were performed in three replicates and the means were used for statistical analysis. The significance level of $5 \%$ was compared with Duncan's test.

\section{Results And Discussion \\ 3.1. MIC and MBC values of FEO}

The MIC and MBC values of FEO are provided in Table 1. The results depicted that in concentrations between 8 and $20 \mathrm{mg} / \mathrm{mL}$, FEO was active against L. monocytogenes, Escherichia coli 0157:H7, P. fluorescens, and S. putrefaciens, respectively. Our results lent support to those of Roby et al. (2013) in evaluating the antimicrobial properties of FEO[20]. Our study also corroborated the study of Ojeda-Sana $\mathrm{AM}$, et al (2013) on rosemary essential oil in that $L$. monocytogenes was the most sensitive bacterium to essential oils [21].

Table 1

The MIC and MBC values of FEO 


\begin{tabular}{lll} 
Bacteria & MIC $(\mathrm{mg} / \mathrm{ml})$ & $\mathrm{MBC}(\mathrm{mg} / \mathrm{ml})$ \\
\hline Listeria monocytogenes & 8.00 & 10.00 \\
\hline O157:H7Escherichia coli & 10.00 & 14.00 \\
\hline Shewanella putrefaciens & 16.00 & 20.00 \\
\hline Pseudomonas fluorescens & 14.00 & 16.00
\end{tabular}

\subsection{Antimicrobial activity of films determined by disc diffusion method}

The antimicrobial activities of films were determined by disk diffusion method. Growth inhibition as the zone of inhibition diameter is given in Table 2. The CMC/PG film showed no antimicrobial activity against the tested bacteria. Moreover, based on the results, $\mathrm{CMC} / \mathrm{PG} / \mathrm{FEO} / \mathrm{TiO}_{2}$ films had the greatest effect on the studied bacteria. As Table 2 shows, $\mathrm{CMC} / \mathrm{PG} / \mathrm{FEO} / \mathrm{TiO}_{2}$ and $\mathrm{CMC} / \mathrm{PG} / \mathrm{FEO}$ treatments had the highest and the lowest antimicrobial effects, especially on L. monocytogenes and S. putrefaciens, respectively. Sani et al. (2017) obtained similar results for $\mathrm{TiO}_{2}$ and rosemary essential oils[18]. Our results also showed that the effect of FEO on Gram positive bacteria was greater than that on Gram negative bacteria; this greater effect is ascribed to the structure of the outer membrane of Gram (-) bacteria, which limits the diffusion of hydrophobic components of FEO to the lipopolysaccharide layer [22]. In general, the antimicrobial effects of $\mathrm{TiO}_{2}$ and $\mathrm{FEO}$ are associated with microbial cell components, destroying the cytoplasmic membrane, affecting cell wall permeability, and affecting biological molecules such as DNA and protein [18]. The antimicrobial effect of FEO is also related to the phenolic compounds called terpenoids [23].

Table 2

Growth inhibition zone of film disks ( $\mathrm{mm}$ )

\begin{tabular}{lllll} 
Bacteria & $\mathrm{CMC} / \mathrm{PG}$ & $\mathrm{CMC} / \mathrm{PG} / \mathrm{F}$ & $\mathrm{CMC} / \mathrm{PG} / \mathrm{TiO}_{2}$ & ${\mathrm{CMC} / \mathrm{PG} / \mathrm{F} / \mathrm{TiO}_{2}}$ \\
\hline Listeria monocytogenes & - & $15.00 \pm 0.34$ & \pm 0.2316 .00 & \pm 0.6719 .00 \\
\hline 0157:H7 Escherichia coli & - & $14.00 \pm 0.12$ & \pm 0.1615 .00 & \pm 0.3416 .00 \\
\hline Shewanella putrefaciens & - & $9.00 \pm 0.09$ & \pm 0.079 .50 & \pm 0.1710 .40 \\
\hline Pseudomonas fluorescens & - & $12.50 \pm 0.13$ & \pm 0.1113 .00 & \pm 0.2514 .00
\end{tabular}

\subsection{Microbial tests}




\subsubsection{Total viable count}

Total viable count (TVC) indicator for rainbow trout fillets kept in refrigerator during storage is shown in Fig. 1. The initial TVC was $3.01 \mathrm{log} C F U / g$, which according to the standards, this level of microbial load in fish fillets indicates the good quality of fish fillets; this result substantiated those of Ojagh SM, et al (2010) [24] and Arashisar Ş, et al (2004) [25]. Control and CMC/PG treatments had very high microbial loads due to the lack of antimicrobial agents during refrigeration, and the lower microbial load of $\mathrm{CMC/PG}$ films compared to the control samples was probably due to the mere film, preventing secondary contamination, reducing available oxygen, and reducing the water available to microorganisms. Compared to the control samples, $\mathrm{CMC} / \mathrm{PG} / \mathrm{FEO}, \mathrm{CMC} / \mathrm{PG} / \mathrm{TiO}_{2}$, and $\mathrm{CMC} / \mathrm{PG} / \mathrm{FEO} / \mathrm{TiO}_{2}$ treatments exerted a significant effect $(P<0.05)$ in reducing the growth rate of bacteria. According to the International Commission on Microbiological Specifications for Foods (ICMSF), the standard log level of microbial load in fish fillets is 7 log CFU/g. Accordingly, CMC/PG/FEO treatment can be stored for 6 days, $\mathrm{CMC} / \mathrm{PG} / \mathrm{TiO}_{2}$ treatment for 9 days, and $\mathrm{CMC} / \mathrm{PG} / \mathrm{FEO} / \mathrm{TiO}_{2}$ treatment for 12 days in the refrigerator. The lowest bacterial growth was observed in $\mathrm{CMC} / \mathrm{PG} / \mathrm{FEO} / \mathrm{TiO}_{2}$ treatment, which is due to the synergistic effect of these two compounds $\left(\mathrm{FEO}\right.$ and $\left.\mathrm{TiO}_{2}\right)$. This result lends support to that of Farshchi E, et al (2019) for the antimicrobial effect of $\mathrm{TiO}_{2}$-Ag [14], and Maghami $\mathrm{M}$, et al (2019) for FEO [26].

\subsubsection{Pseudomonas spp. count}

Pseudomonas spp. are Gram (-), highly aerobic, and $\mathrm{CO}_{2}$-sensitive bacteria [27]. As shown in Fig. 2, compared to the control group, the significant effect of treatments with antimicrobial compounds was observed on the growth rate of Pseudomonas spp. $(P<0.05)$. The initial $P$ seudomonas spp. value for all treatments was $3.02 \mathrm{log} \mathrm{CFU} / \mathrm{g}$ on the first day and $7.87 \mathrm{log} \mathrm{CFU} / \mathrm{g}$ on the 12th day for the control samples. CMC/PG treatment was not a good barrier to the growth of these microorganisms due to the lack of antimicrobial compounds, but treatments containing $\mathrm{FEO}$ and $\mathrm{TiO}_{2}$ significantly reduced the growth rate of these microorganisms $(P<0.05)$; this result substantiates the results of Sani MA, et al (2017) [18] For $\mathrm{TiO}_{2}$, Maghami M, et al (2019) [26] and Kivanç M, Akgül A (1986) [28] for FEO. A decrease in the antimicrobial effects of $\mathrm{CMC} / \mathrm{PG} / \mathrm{FEO}, \mathrm{CMC} / \mathrm{PG} / \mathrm{TiO}_{2}$, and $\mathrm{CMC} / \mathrm{PG} / \mathrm{FEO} / \mathrm{TiO}_{2}$ treatments in the last days was attributed to the decrease in the release of these substances.

\subsubsection{Lactic Acid Bacteria}

LAB are optional anaerobic bacteria that grow in low concentrations of $\mathrm{O}_{2}$. They make up a significant portion of the meat's natural microflora. As Fig. 3 displays, the LAB content for the treatments on the first day was $2.0 \log \mathrm{CFU} / \mathrm{g}$, which increased during the maintenance period and for the control sample reached $5.67 \mathrm{log} \mathrm{CFU} / \mathrm{g}$. CMC/PG/FEO, $\mathrm{CMC} / \mathrm{PG} / \mathrm{TiO}_{2}$, and $\mathrm{CMC} / \mathrm{PG} / \mathrm{FEO} / \mathrm{TiO}_{2}$ treatments significantly 
reduced the growth rate of $\mathrm{LAB}$ compared to the control samples $(P<0.05)$, Maghami M, et al $(2019)$ for FEO [26] and Sani MA, et al (2017) for $\mathrm{TiO}_{2}$ [18] achieved the same results on LAB. On the last day, the lowest level of $\mathrm{LAB}$ was related to $\mathrm{CMC} / \mathrm{PG} / \mathrm{FEO} / \mathrm{TiO}_{2}$ treatment, which was due to the synergistic effect of two antimicrobial agents.

\subsubsection{Enterobacteriaceae count}

Enterobacteriaceae microorganisms are health indicators and part of the natural microbial flora of rainbow trout [29]. Based on the results, the initial level of Enterobacteriaceae was $2.12 \mathrm{log} \mathrm{CFU} / \mathrm{g}$, which indicates the good quality of the meat (Fig. 4) [18]. During the storage period, the number of Enterobacteriaceae increased and reached $6.21 \mathrm{log} \mathrm{CFU} / \mathrm{g}$ on day 15 for the control sample. On the 15th day, the number of Enterobacteriaceae for $\mathrm{CMC} / \mathrm{PG} / \mathrm{FEO} / \mathrm{TiO}_{2}$ treatment was $3.99 \mathrm{log} \mathrm{CFU} / \mathrm{g}$ which showed the favorable effect of antimicrobial agents. $\mathrm{FEO}$ and $\mathrm{TiO}_{2}$ reduced the growth of Enterobacteriaceae compared to the control sample $(P<0.05)$; this shares a number of similarities with the results of Österblad M, et al (1999) [30], Kačániová M, et al (2019) [31] and Sani MA, et al (2017) [18]. Furthermore, the synergistic effect of $\mathrm{FEO}$ and $\mathrm{TiO}_{2}$ was quite evident in reducing the growth of Enterobacteriaceae.

\subsubsection{Psychrotrophic bacteria}

Changes in psychrotrophic bacteria for treatments during refrigeration are shown in Fig. 5. The initial number of psychrotrophic bacteria at the beginning of the period was $3.42 \mathrm{log} \mathrm{CFU} / \mathrm{g}$. Over time, the number of these bacteria increased in all treatments, and in the control samples reached $8.77 \mathrm{log} \mathrm{CFU} / \mathrm{g}$ in the end of the period, which was very high. The difference between the control samples and $\mathrm{CMC} / \mathrm{PG} / \mathrm{FEO} / \mathrm{TiO}_{2}$ treatment in the end of the period was about $2 \log \mathrm{CFU} / \mathrm{g}$, which indicates the favorable antimicrobial effect of $\mathrm{TiO}_{2}$ and FEO $(P<0.05)$. These results concurred well with the results of Mazandrani HA, Javadian S, Bahram S (2016) [32] and Bagheri R, et al (2016) [33] for the antimicrobial effect of FEO on silver carp and common kilka, respectively, and the results of Alizadeh-Sani M, et al (2020) [34] for $\mathrm{TiO}_{2}$.

\section{4. $\mathrm{pH}$}

The $\mathrm{pH}$ changes of fish fillets during the storage period are shown in Fig. 6 . The initial $\mathrm{pH}$ of the fish fillet was 6.33, which was consistent with the pH levels in the studies of Arashisar Ş, et al (2004) [25] and Gimenez B, et al (2002) [35] for rainbow trout. The pH level decreased until the third day due to the glycolysis process of fish [36]. During this period, the $\mathrm{pH}$ increased and bacterial metabolites, and microbial enzymes produced in the fillet tissue [37]. By increasing the $\mathrm{pH}$, the quality characteristics of the 
fish fillets decreased. Treatments with antimicrobial agents significantly kept the $\mathrm{pH}$ at lower levels than that in the control samples; this was consistent with the results of the microbial part.

\subsection{Thiobarbituric acid (TBA)}

TBA changes of different treatments of fish fillets during refrigeration are shown in Fig. 7. The initial TBA level of fish fillets was determined to be $0.13 \mathrm{mgMDA} / \mathrm{Kg}$, which was in the same level of that in the study of Ojaq et al. (2010) for rainbow trout. In all treatments, the amount of TBA increased over time $(P<0.05)$. Perumalla AVS, Hettiarachchy NS (2011) [38] showed that essential oil reduces the amount of TBA in samples by various mechanisms such as preventing the onset of radical formation, and reducing the transfer of metal ion catalysts, as well as peroxide decomposition and reaction with free radicals [39]. TBA level is about 1-2 mgMDA/Kg in fish fillets, which is the starting point for an unpleasant odor. However, in general, less than $5 \mathrm{mgMDA} / \mathrm{Kg}$ is desirable for consumption [40]. The effect of $\mathrm{TiO}_{2}$ on the reduction of TBA was much less than that of $\mathrm{FEO}$, because $\mathrm{TiO}_{2}$ has antimicrobial properties and FEO has high antioxidant properties in general, and as a result, these further reduce the TBA level. The film around the fish fillets also reduced the TBA level by reducing the amount of oxygen available. The trend of change is consistent with the results of Ojagh SM, et al (2010) [24] obtained for rainbow trout.

\subsection{Sensory evaluation}

As depicted in Fig. 8, the quality of sensory indicators decreased over time $(P<0.05)$. Odor index under the influence of $\mathrm{TiO}_{2}$ and $\mathrm{FEO}$ treatments scored higher than the control sample because odor is one of the most sensitive indicators in fish fillets that is strongly influenced by storage conditions, microbial load, and chemical reactions. The color index was not significantly affected during the storage and all samples had a relatively high score. Microbial activity and chemical reactions that occur during fillet storage have less effect on the color index. The tissue of fish fillets was severely affected by the storage time and treatments, and in the control samples, due to the bacterial growth and chemical reactions, the surface of the fish fillets became viscous and soft, and had an undesirable texture. $\mathrm{TiO}_{2}$ and $\mathrm{FEO}$ treatments were significantly lower $(P<0.05)$ due to the reduction of microbial growth and chemical reactions. The overall acceptance index decreased during the storage; and considering the acceptance limit of 5 , the samples treated with $\mathrm{TiO}_{2}$ and FEO could be easily used up to day 6 . This result is completely consistent with the results obtained in the microbial stage.

\section{Conclusion}

To determine the microbial properties of the films, disk diffusion test was performed, which showed that the films with $\mathrm{TiO}_{2}$ and $\mathrm{FEO}$ had a significant antimicrobial effect. To determine the antimicrobial effect of the films on food models, 4 film treatments were prepared and rainbow trout were covered with the produced films. During the refrigeration, the TVC, LAB, Enterobacteriaceae, Pseudomonas spp., and 
psychrotrophic bacteria were quantified. The results showed that films containing antimicrobial compounds of $\mathrm{FEO}$ and $\mathrm{TiO}_{2}$ significantly reduced the bacterial growth during the refrigeration. When FEO and $\mathrm{TiO}_{2}$ were used simultaneously in the film, the growth of microorganisms was severely reduced due to their synergistic properties. Samples treated up to day 6 received acceptable scores in terms of sensory evaluation. Based on the results, in general, the use of $\mathrm{FEO}$ and $\mathrm{TiO}_{2}$ in biodegradable films improves the antimicrobial, chemical, and sensory properties of rainbow trout fillets.

\section{Declarations}

\section{Conflict of interest:}

The authors declare they have no financial interests.

\section{Funding:}

The research leading to these results received funding from Ferdowsi University of Mashhad under Grant Agreement No. 51247

\section{References}

1. Samsi MS, Kamari A, Din SM, Lazar G (2019) Synthesis, characterization and application of gelatincarboxymethyl cellulose blend films for preservation of cherry tomatoes and grapes. J Food Sci Technol 56:3099-3108

2. Kumari M, Mahajan H, Joshi R, Gupta M (2017) Development and structural characterization of edible films for improving fruit quality. Food Packag shelf life 12:42-50

3. Hanani ZAN, Roos YH, Kerry JP (2014) Use and application of gelatin as potential biodegradable packaging materials for food products. Int J Biol Macromol 71:94-102

4. Youssef AM, El-Sayed SM (2018) Bionanocomposites materials for food packaging applications: Concepts and future outlook. Carbohydr Polym 193:19-27

5. Muppalla SR, Kanatt SR, Chawla SP, Sharma A (2014) Carboxymethyl cellulose-polyvinyl alcohol films with clove oil for active packaging of ground chicken meat. Food Packag Shelf Life 2:51-58

6. Ballesteros LF, Cerqueira MA, Teixeira JA, Mussatto SI (2018) Production and physicochemical properties of carboxymethyl cellulose films enriched with spent coffee grounds polysaccharides. Int J Biol Macromol 106:647-655

7. Fadavi G, Mohammadifar MA, Zargarran A et al (2014) Composition and physicochemical properties of Zedo gum exudates from Amygdalus scoparia. Carbohydr Polym 101:1074-1080

8. Hadian M, Hosseini SMH, Farahnaky A et al (2016) Isothermal titration calorimetric and spectroscopic studies of $\beta$-lactoglobulin-water-soluble fraction of Persian gum interaction in aqueous solution. Food Hydrocoll 55:108-118 
9. Dai L, Qiu C, Xiong L, Sun Q (2015) Characterisation of corn starch-based films reinforced with taro starch nanoparticles. Food Chem 174:82-88

10. Hasheminya S-M, Mokarram RR, Ghanbarzadeh B et al (2019) Development and characterization of biocomposite films made from kefiran, carboxymethyl cellulose and Satureja Khuzestanica essential oil. Food Chem 289:443-452

11. Upadhyay RK (2015) GC-MS analysis and in vitro antimicrobial susceptibility of Foeniculum vulgare seed essential oil. Am J Plant Sci 6:1058

12. Shankar S, Wang L-F, Rhim J-W (2017) Preparation and properties of carbohydrate-based composite films incorporated with CuO nanoparticles. Carbohydr Polym 169:264-271

13. Oleyaei SA, Zahedi Y, Ghanbarzadeh B, Moayedi AA (2016) Modification of physicochemical and thermal properties of starch films by incorporation of TiO2 nanoparticles. Int J Biol Macromol 89:256-264

14. Farshchi E, Pirsa S, Roufegarinejad L et al (2019) Photocatalytic/biodegradable film based on carboxymethyl cellulose, modified by gelatin and TiO2-Ag nanoparticles. Carbohydr Polym 216:189196

15. Maleki M, Mohsenzadeh M (2020) Optimization of Biodegradable Film Production Based on Carboxymethyl Cellulose and Persian Gum by Response Surface Methodology. Food Sci Technol $17: 41-50$

16. Mohsenabadi N, Rajaei A, Tabatabaei M, Mohsenifar A (2018) Physical and antimicrobial properties of starch-carboxy methyl cellulose film containing rosemary essential oils encapsulated in chitosan nanogel. Int J Biol Macromol 112:148-155

17. Azarifar M, Ghanbarzadeh B, Khiabani MS et al (2019) The optimization of gelatin-CMC based active films containing chitin nanofiber and Trachyspermum ammi essential oil by response surface methodology. Carbohydr Polym 208:457-468

18. Sani MA, Ehsani A, Hashemi M (2017) Whey protein isolate/cellulose nanofibre/TiO2 nanoparticle/rosemary essential oil nanocomposite film: Its effect on microbial and sensory quality of lamb meat and growth of common foodborne pathogenic bacteria during refrigeration. Int $\mathrm{J}$ Food Microbiol 251:8-14

19. Kirk S, Sawyer R (1991) Pearson's composition and analysis of foods. Longman Group Ltd.

20. Roby MHH, Sarhan MA, Selim KA-H, Khalel KI (2013) Antioxidant and antimicrobial activities of essential oil and extracts of fennel (Foeniculum vulgare L.) and chamomile (Matricaria chamomilla L.). Ind Crops Prod 44:437-445

21. Ojeda-Sana AM, van Baren CM, Elechosa MA et al (2013) New insights into antibacterial and antioxidant activities of rosemary essential oils and their main components. Food Control 31:189195

22. Burt S (2004) Essential oils: their antibacterial properties and potential applications in foods-a review. Int J Food Microbiol 94:223-253 
23. Hyldgaard M, Mygind T, Meyer RL (2012) Essential oils in food preservation: mode of action, synergies, and interactions with food matrix components. Front Microbiol 3:12

24. Ojagh SM, Rezaei M, Razavi SH, Hosseini SMH (2010) Effect of chitosan coatings enriched with cinnamon oil on the quality of refrigerated rainbow trout. Food Chem 120:193-198

25. Arashisar Ş, Hisar O, Kaya M, Yanik T (2004) Effects of modified atmosphere and vacuum packaging on microbiological and chemical properties of rainbow trout (Oncorynchus mykiss) fillets. Int J Food Microbiol 97:209-214

26. Maghami M, Motalebi AA, Anvar SAA (2019) Influence of chitosan nanoparticles and fennel essential oils (Foeniculum vulgare) on the shelf life of Huso huso fish fillets during the storage. Food Sci Nutr 7:3030-3041

27. Jay JM, Loessner MJ, Golden DA (2005) Indicators of food microbial quality and safety. Mod food Microbiol 473-495

28. Kivanç M, Akgül A (1986) Antibacterial activities of essential oils from Turkish spices and citrus. Flavour Fragr J 1:175-179

29. Mexis SF, Chouliara E, Kontominas MG (2009) Combined effect of an oxygen absorber and oregano essential oil on shelf life extension of rainbow trout fillets stored at 4 C. Food Microbiol 26:598-605

30. Österblad M, Pensala O, Peterzéns M et al (1999) Antimicrobial susceptibility of Enterobacteriaceae isolated from vegetables. J Antimicrob Chemother 43:503-509

31. Kačániová M, Mellen M, Vukovic NL et al (2019) Combined effect of vacuum packaging, fennel and savory essential oil treatment on the quality of chicken thighs. Microorganisms 7:134

32. Mazandrani HA, Javadian S, Bahram S (2016) The effect of encapsulated fennel extracts on the quality of silver carp fillets during refrigerated storage. Food Sci Nutr 4:298-304

33. Bagheri R, Izadi Amoli R, Tabari Shahndasht N, Shahosseini SR (2016) Comparing the effect of encapsulated and unencapsulated fennel extracts on the shelf life of minced common kilka (C lupeonella cultriventris caspia) and P seudomonas aeruginosa inoculated in the mince. Food Sci Nutr 4:216-222

34. Alizadeh-Sani M, Mohammadian E, McClements DJ (2020) Eco-friendly active packaging consisting of nanostructured biopolymer matrix reinforced with TiO2 and essential oil: Application for preservation of refrigerated meat. Food Chem 322:126782

35. Gimenez B, Roncales P, Beltran JA (2002) Modified atmosphere packaging of filleted rainbow trout. J Sci Food Agric 82:1154-1159

36. Jung S, Ghoul M, de Lamballerie-Anton M (2003) Influence of high pressure on the color and microbial quality of beef meat. LWT-food Sci Technol 36:625-631

37. Fan W, Sun J, Chen Y et al (2009) Effects of chitosan coating on quality and shelf life of silver carp during frozen storage. Food Chem 115:66-70

38. Perumalla AVS, Hettiarachchy NS (2011) Green tea and grape seed extracts-Potential applications in food safety and quality. Food Res Int 44:827-839 
39. Faleiro L, Miguel G, Gomes S et al (2005) Antibacterial and antioxidant activities of essential oils isolated from Thymbra capitata L.(Cav.) and Origanum vulgare L. J Agric Food Chem 53:8162-8168 40. Sallam KI (2007) Antimicrobial and antioxidant effects of sodium acetate, sodium lactate, and sodium citrate in refrigerated sliced salmon. Food Control 18:566-575

\section{Figures}

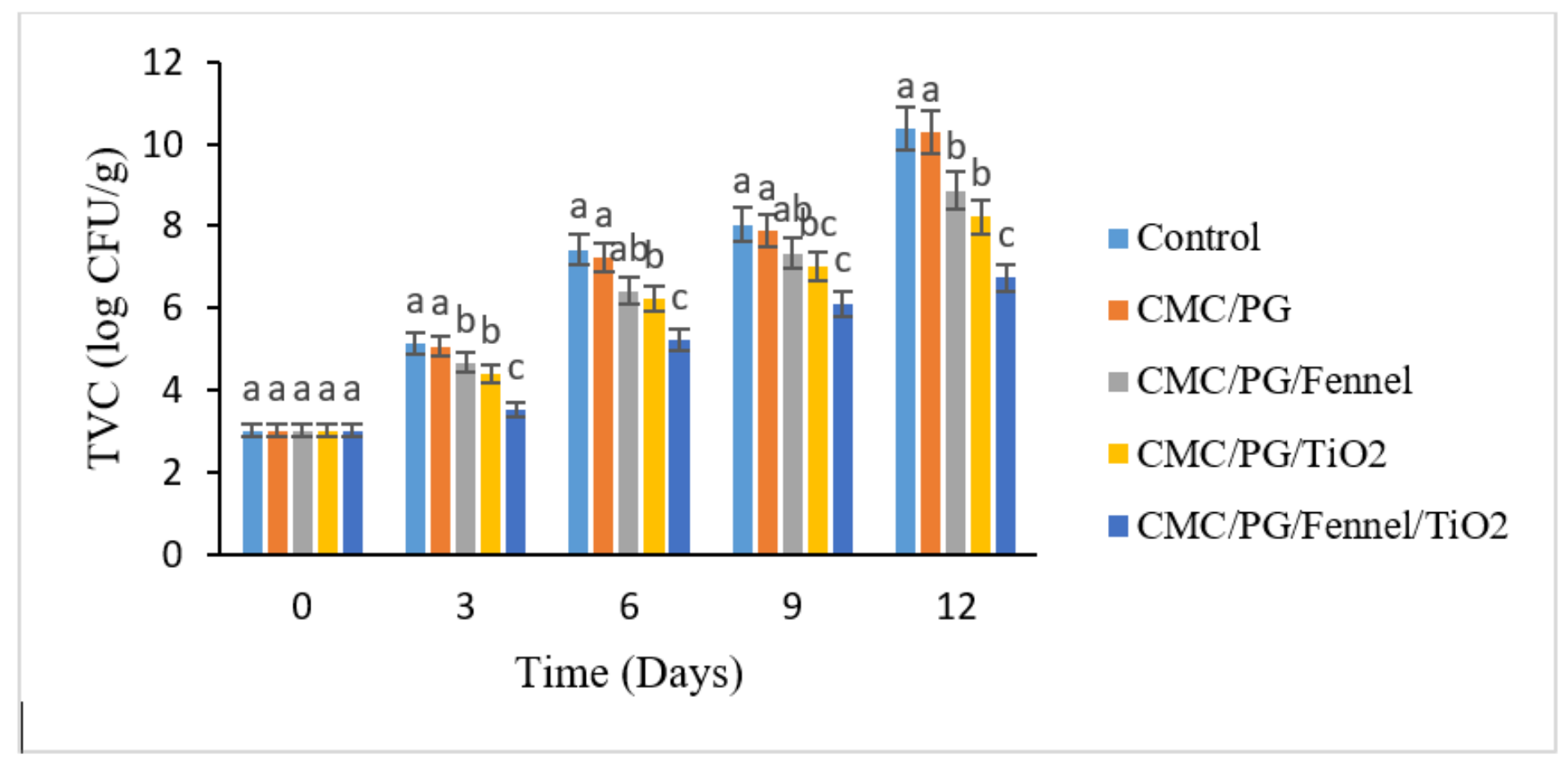

\section{Figure 1}

Changes in TVC of different treatments during storage at $4^{\circ} \mathrm{C}$ for 12 days 


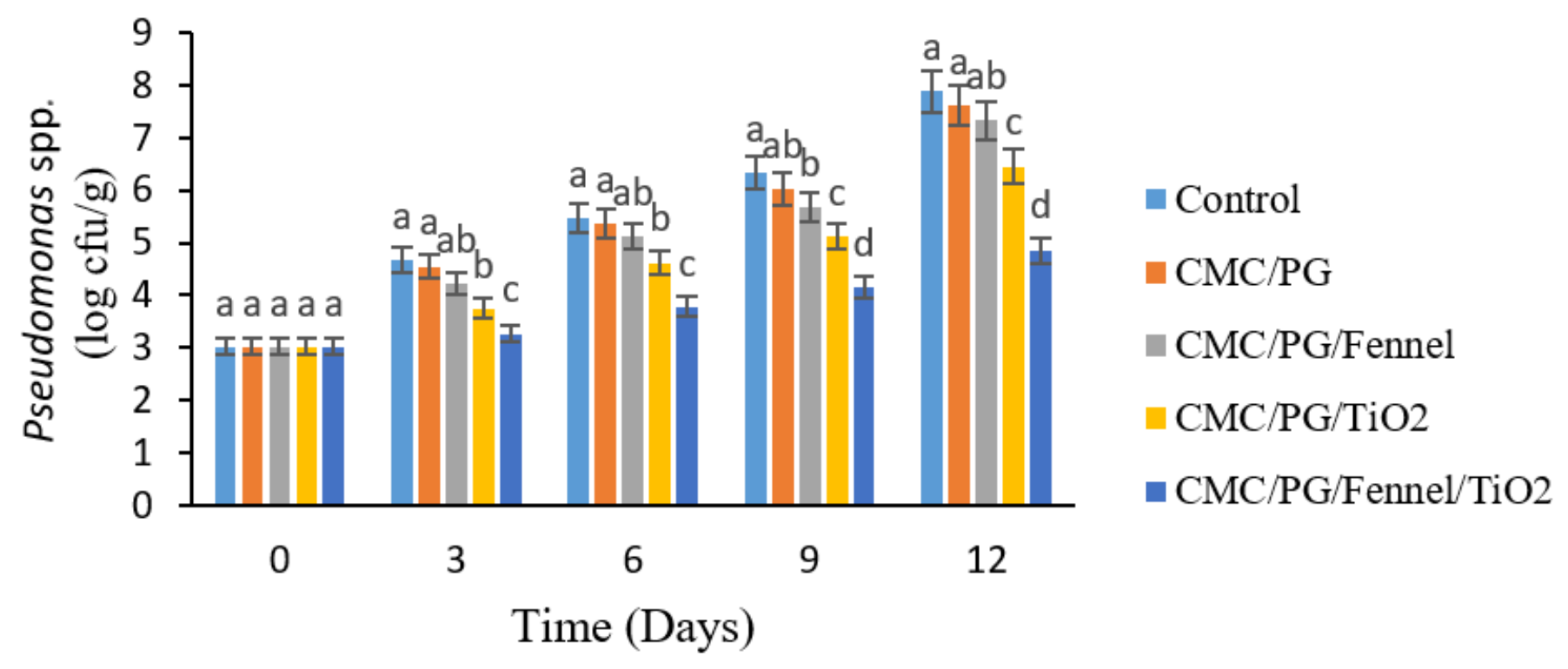

Figure 2

Changes in Pseudomonas spp. Count of different treatments during storage at $4^{\circ} \mathrm{C}$ for 12 days

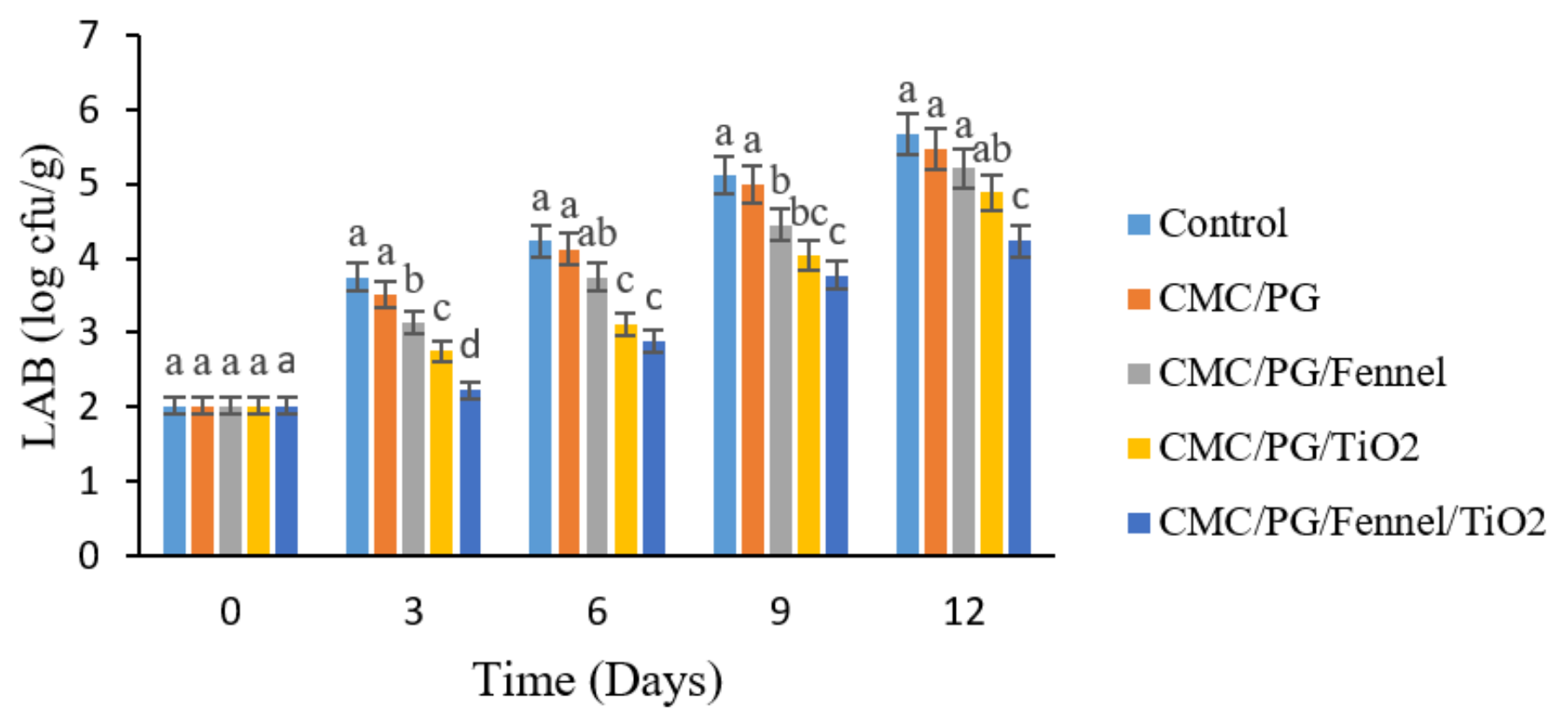

Figure 3

Changes in $L A B$ of different treatments during storage at $4^{\circ} \mathrm{C}$ for 12 days 


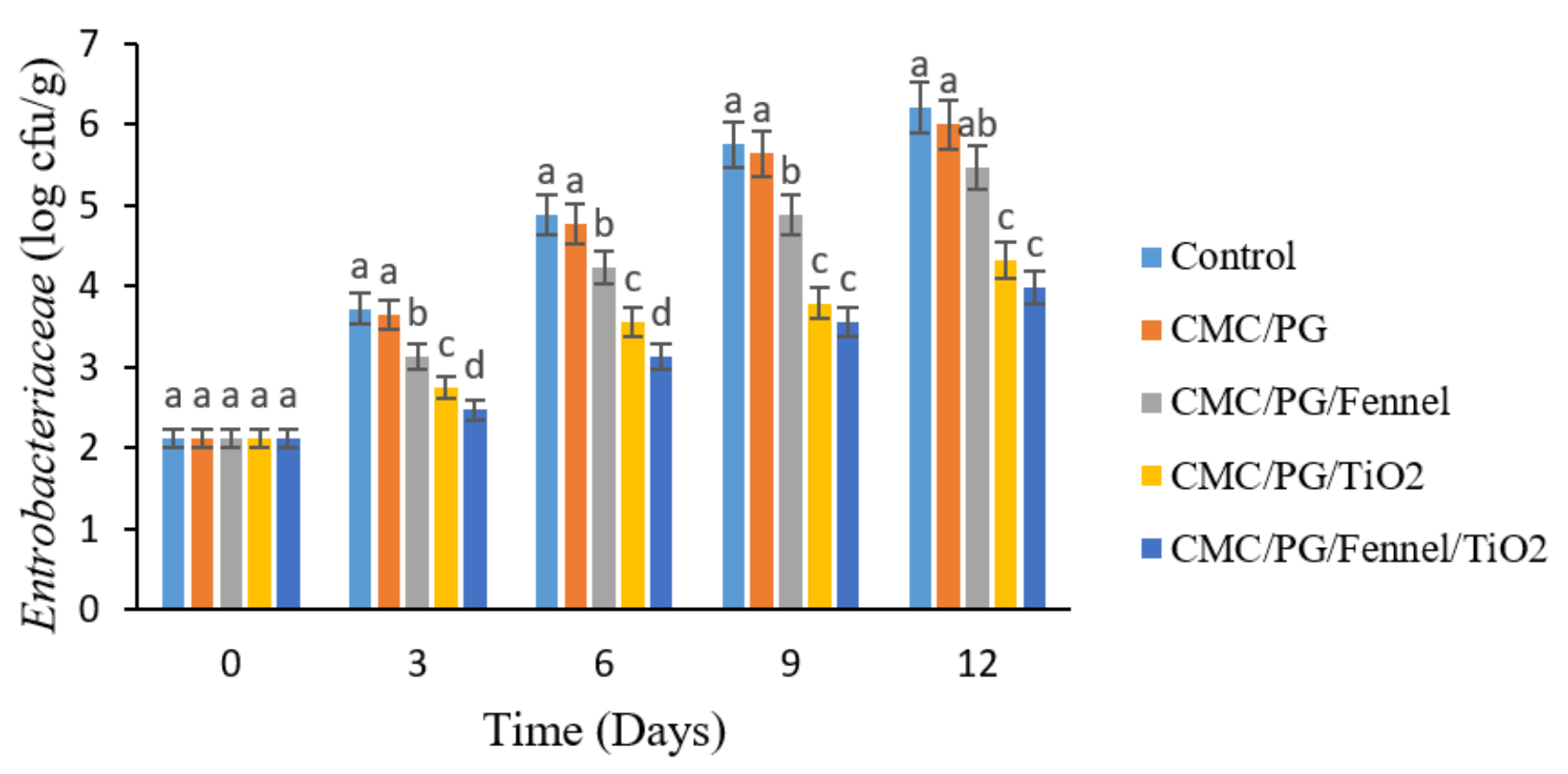

Figure 4

Changes in Enterobacteriaceae count of different treatments during storage at $4^{\circ} \mathrm{C}$ for 12 days

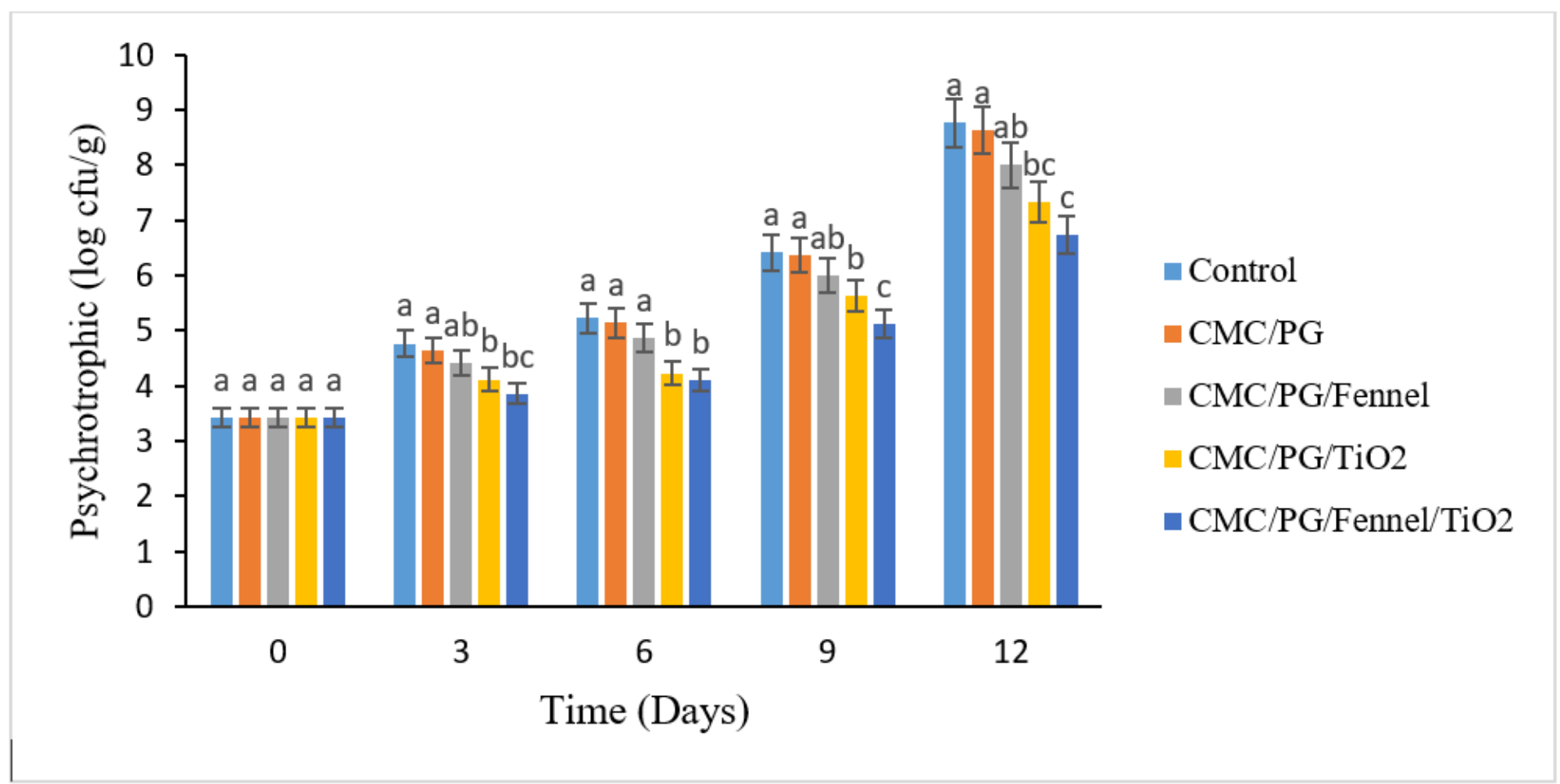

Figure 5

Changes in Psychrotrophic bacteria of different treatments during storage at $4^{\circ} \mathrm{C}$ for 12 days 


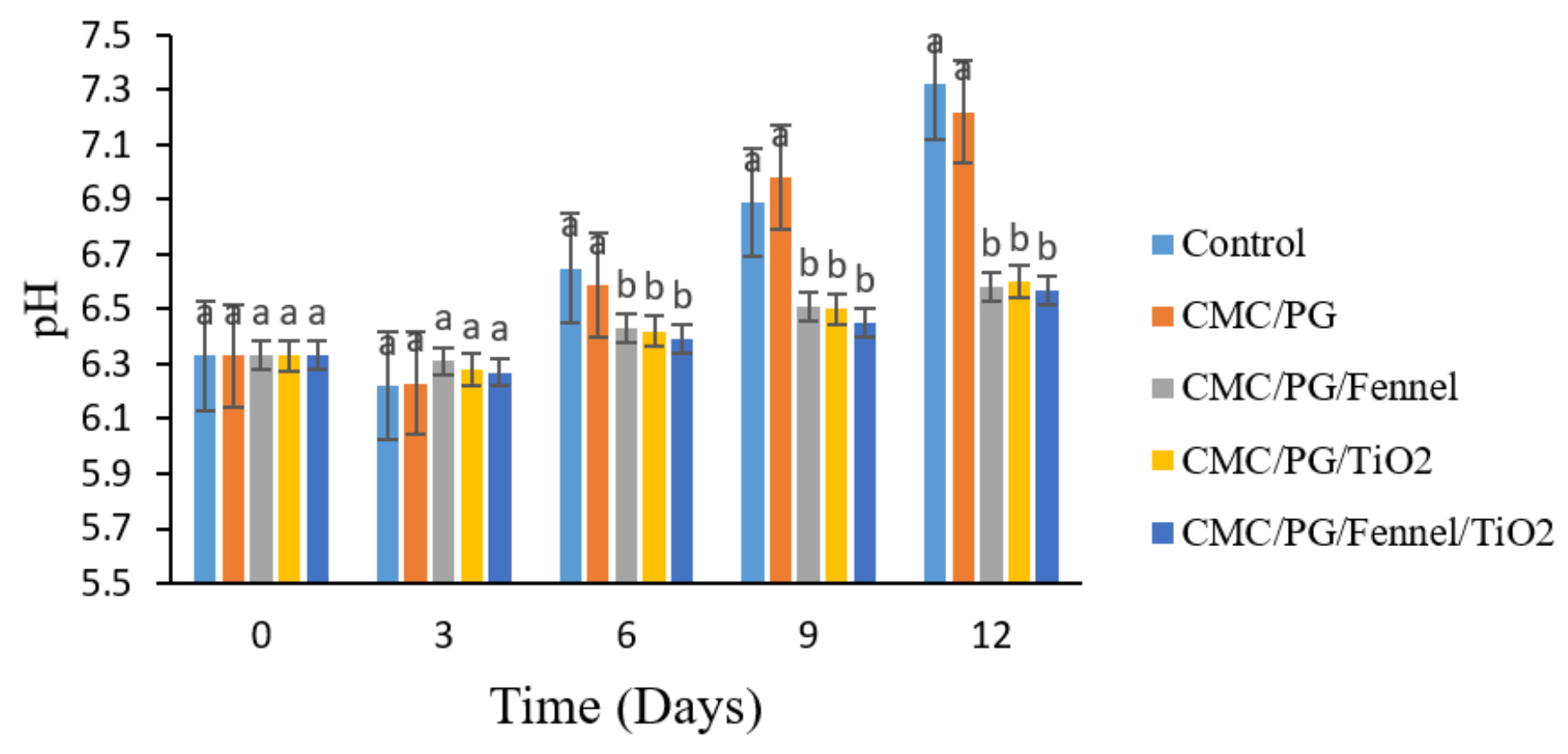

Figure 6

Changes in $\mathrm{pH}$ of different treatments during storage at $4^{\circ} \mathrm{C}$ for 12 days

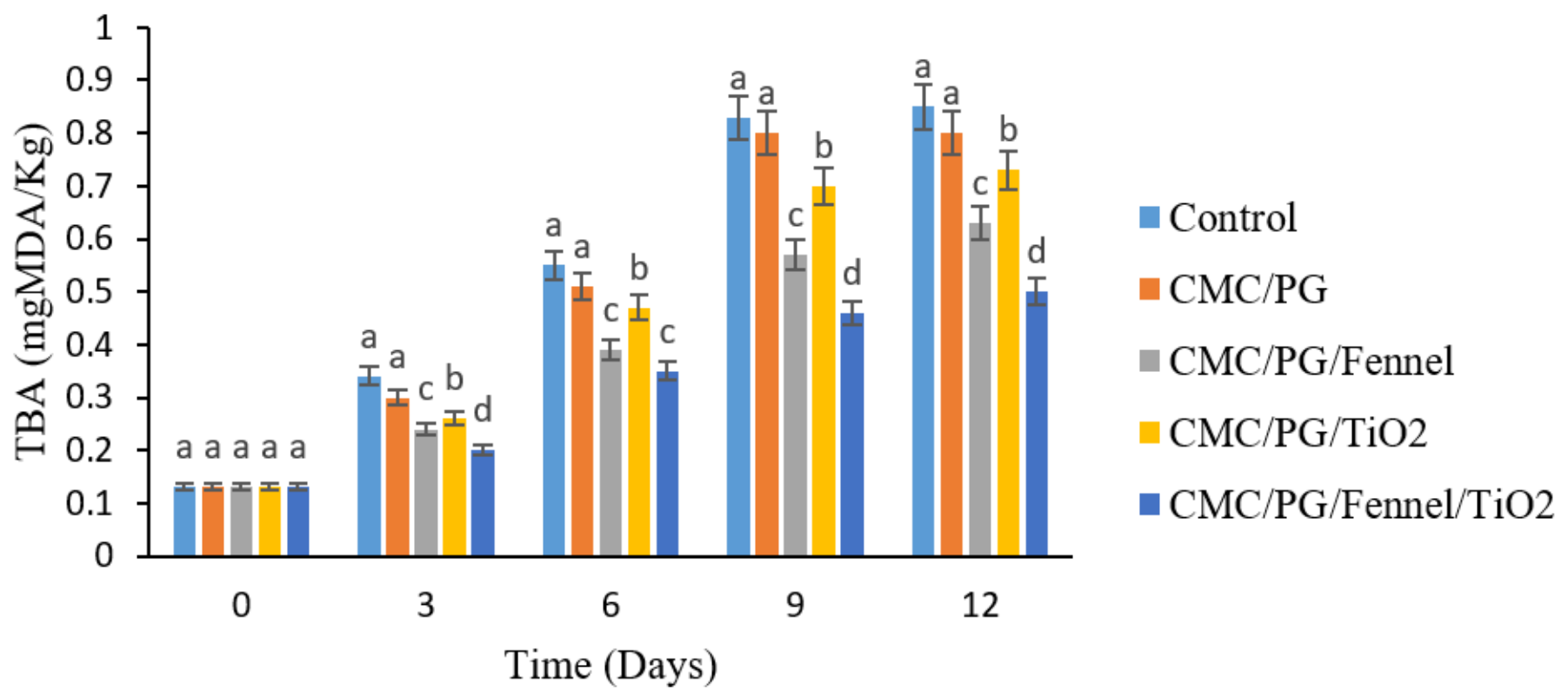

Figure 7

Changes in TBA of different treatments during storage at $4^{\circ} \mathrm{C}$ for 12 days 

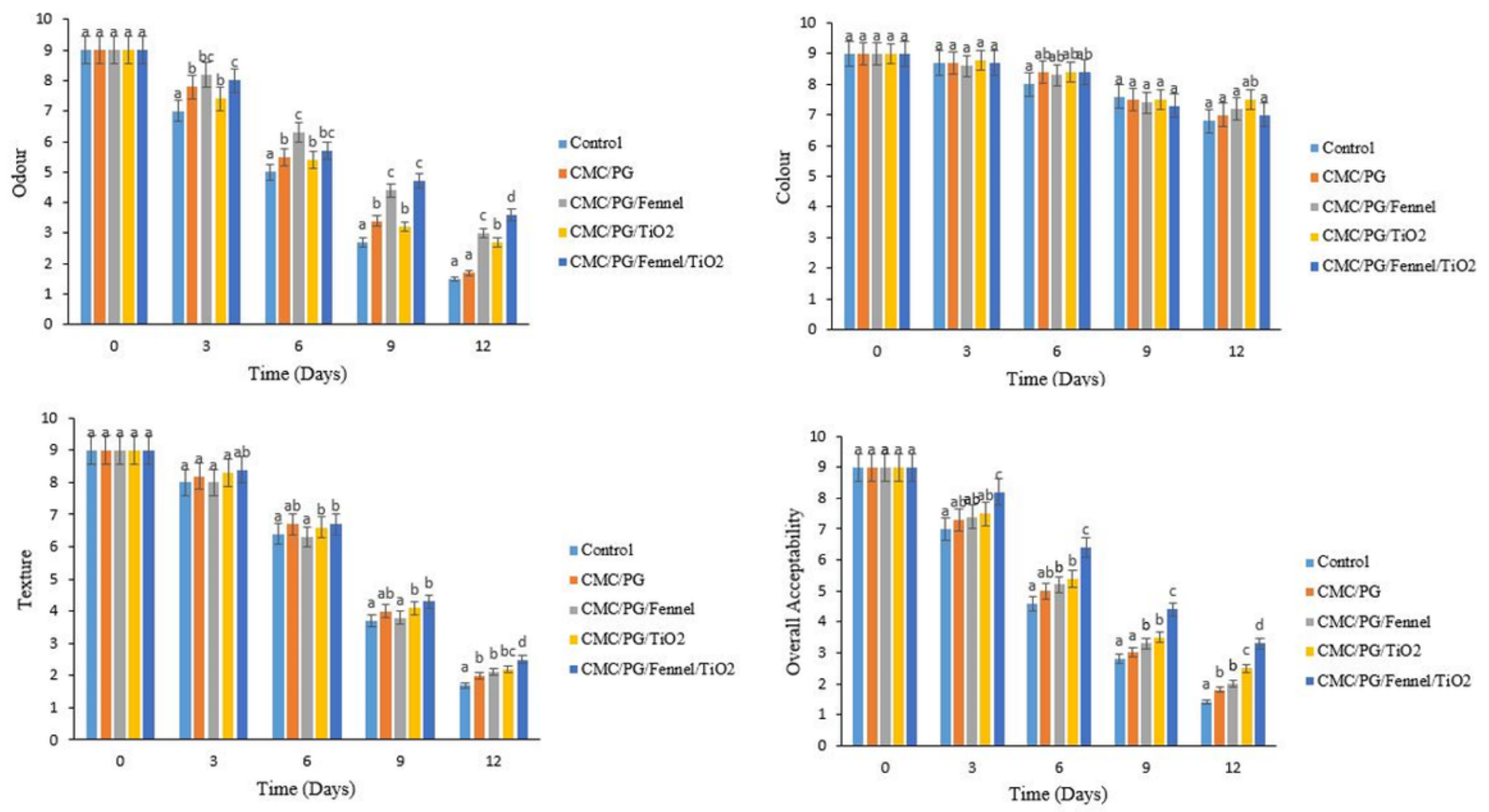

Figure 8

Changes in Sensory evaluation of different treatments during storage at $4^{\circ} \mathrm{C}$ for 12 days 